\title{
Different durations of whole raw soybean supplementation during the prepartum period: Measures of cellular immune function in transition cows
}

\author{
R. Gardinal, ${ }^{*}$ G. D. Calomeni, ${ }^{,}$F. Zanferari, ${ }^{*}$ T. H. A. Vendramini, ${ }^{*}$ C. S. Takiya, ${ }^{*}$ H. G. Bertagnon, $\dagger$ \\ C. F. Batista, $†$ A. M. M. P. Della Libera, $†$ and F. P. Renno* $\ddagger^{1}$ \\ *Department of Animal Nutrition and Production, University of Sao Paulo, Pirassununga, Brazil, 13635-900 \\ †Department of Internal Medicine, University of Sao Paulo, Sao Paulo, Brazil, 05508-270 \\ łBursar 1-C of the National Council of Scientific and Technologic Development, Brasilia, Brazil, 71605-001
}

\begin{abstract}
The objective of this study was to evaluate different durations of whole raw soybean (WS) supplementation (diet rich in n-6 fatty acid) during the prepartum period on cellular immune function of dairy cows in the transition period and early lactation. Thirty-one Holstein cows were used in a completely randomized design and assigned to 4 experimental groups (G) [G90, G60, G30, and G0 (control)] supplemented with a diet containing $12 \%$ of WS from 90,60, 30 and $0 \mathrm{~d}$ relative to the calving date, respectively. Cows were dried off $60 \mathrm{~d}$ before the expected calving date. After parturition, all cows were fed a diet containing $12 \%$ of WS until 84 DIM. Blood samples were collected before the morning feeding $(\mathrm{d}-56 \pm 2,-28 \pm 2,-14 \pm 2,-7$ \pm 2 , at the day of partum, $7 \pm 2,14 \pm 2,28 \pm 2$, and $56 \pm 2$ relative to parturition). Cell phenotyping and phagocytosis assays were carried out using monoclonal antibodies and flow cytometry technique. Duration of WS supplementation linearly increased the percentage of blood CD $3^{+}$cells, as well as increased the percentage of blood $\mathrm{CD} 8^{+}$cells in the postpartum period, notably in G30, whereas the lowest values were observed in G0. Further, the duration of WS supplementation linearly increased the reactive oxygen species median fluorescence intensity of $\mathrm{CH} 138^{+}$cells after phagocytizing Staphylococcus aureus in the postpartum period. Longer periods of WS supplementation linearly increased phagocytosis median fluorescence intensity of $\mathrm{CH} 138^{+}$ cells in the prepartum period of cows. Duration of WS supplementation linearly increased the percentage of blood $\mathrm{CD}_{14}{ }^{+}$cells producing reactive oxygen species when stimulated either by Staph. aureus or Escherichia
\end{abstract}

Received October 17, 2016.

Accepted July 15, 2017.

${ }^{1}$ Corresponding author: francisco.renno@usp.br coli in the postpartum period. In conclusion, longer periods of WS supplementation during late lactation and the dry period (beginning on d 90 of the expected calving date) alter the leukocyte population and improve neutrophil immune response in the postpartum period with no detrimental effects on cow performance.

Key words: adaptive immunity, innate immunity, oxidative burst, linoleic acid, phagocytosis

\section{INTRODUCTION}

The immune system is composed of the innate and the adaptive systems that operate in a synchronized, sequential, and complementary manner to prevent diseases (Carroll and Forsberg, 2007). The innate immune system is responsible for combating the first infection stages and delays pathogen propagation into the organism. If the innate immune system fails to eliminate the pathogen, the adaptive system is triggered and it develops a specific response including the production of antigen-specific lymphocytes and memory cells able to identify antigenic determinants of a pathogen (Tizard, 2014; Sordillo, 2016).

Hormonal and physiological changes occurring in the transition period and early lactation, such as increased blood cortisol and nonesterified fatty acid (NEFA) concentration, and decreased energy balance often jeopardize the immune response of cows. These changes reduce immune cellular activity (Cai et al., 1994; Zerbe et al., 2000), impair cellular migration to peripheral tissue (Kimura et al., 1999), and decrease cell bactericidal and phagocytic activities (Kehrli et al., 1989) and reactive oxygen species (ROS) production, especially in neutrophils and monocytes (Mehrzad et al., 2001; Singh et al., 2008).

Research evaluating the supplementation of PUFA to dairy cows has found PUFA may either stimulate (proinflammatory; Grummer et al., 2004) or inhibit (antiinflammatory; Calder, 2012) the immune system. Poly- 
unsaturated fatty acids may alter the fatty acid (FA) profile of cell membranes, modifying the production of pro- or anti-inflammatory molecules including cytokines, IL, and leukotrienes. In addition, PUFA influence the expression of adhesion molecules, and proliferation and activation of immune cells (Contreras and Sordillo, 2011). The different outcomes of PUFA supplementation on the immune system are mostly attributed to the type of FA provided. Polyunsaturated FA of n-3 and n-6 series may modulate immune response (Gandra et al., 2016a) depending on the processing method of FA (rumen protected or as a free oil) and their proportion in the diet (Onetti and Grummer, 2004; Greco et al., 2015). The n-3 FA have anti-inflammatory properties, whereas the n-6 FA possess pro-inflammatory properties (Silvestre et al., 2011; Calder, 2012).

Linoleic acid is a FA from the n-6 series, commonly supplemented in animal and human diets. In the immune cells, linoleic acid acts as a precursor for arachidonic acid synthesis, a major component of pro-inflammatory molecules and activator of immune cells (Sordillo et al., 2009). In humans and rodents, linoleic acid supplementation directly influences innate immunity by increas- ing the adhesion molecule expression in neutrophils, enhancing phagocytic activity, promoting bacterial killing by increasing ROS production in polymorphonuclear cells, and altering the synthesis of intracellular signaling molecules in immune cells (Contreras and Sordillo, 2011; Poorani et al., 2016). Studies that evaluated the supplementation of rumen-protected sources of linoleic acid to dairy cattle have shown similar responses to linoleic acid provision to humans regarding the immune system (Silvestre et al., 2011; Gandra et al., 2016a).

The major nutrient in whole raw soybean (WS) is protein; however, it is also rich in linoleic acid. Further, oilseeds have a protein surrounding their lipid content that partially protects FA against ruminal biohydrogenation (Lock and Bauman, 2004; Barletta et al., 2016). The partial biohydrogenation of linoleic acid produces trans-11 C18:1 FA and cis-9,trans-11 C18:2 CLA (Jenkins et al., 2008). However, recent in vivo or ex vivo studies have demonstrated that CLA has a minor effect on immune response of cows (Petzold et al., 2015; Eger et al., 2017).

Although the effects of n-6 FA supplementation have been extensively investigated, research evaluating their

Table 1. Percentage of blood granulocytes and mononuclear cells expressing specific adhesion molecules in dairy cows fed whole raw soybeans during different periods (mean $\pm \mathrm{SD}$ )

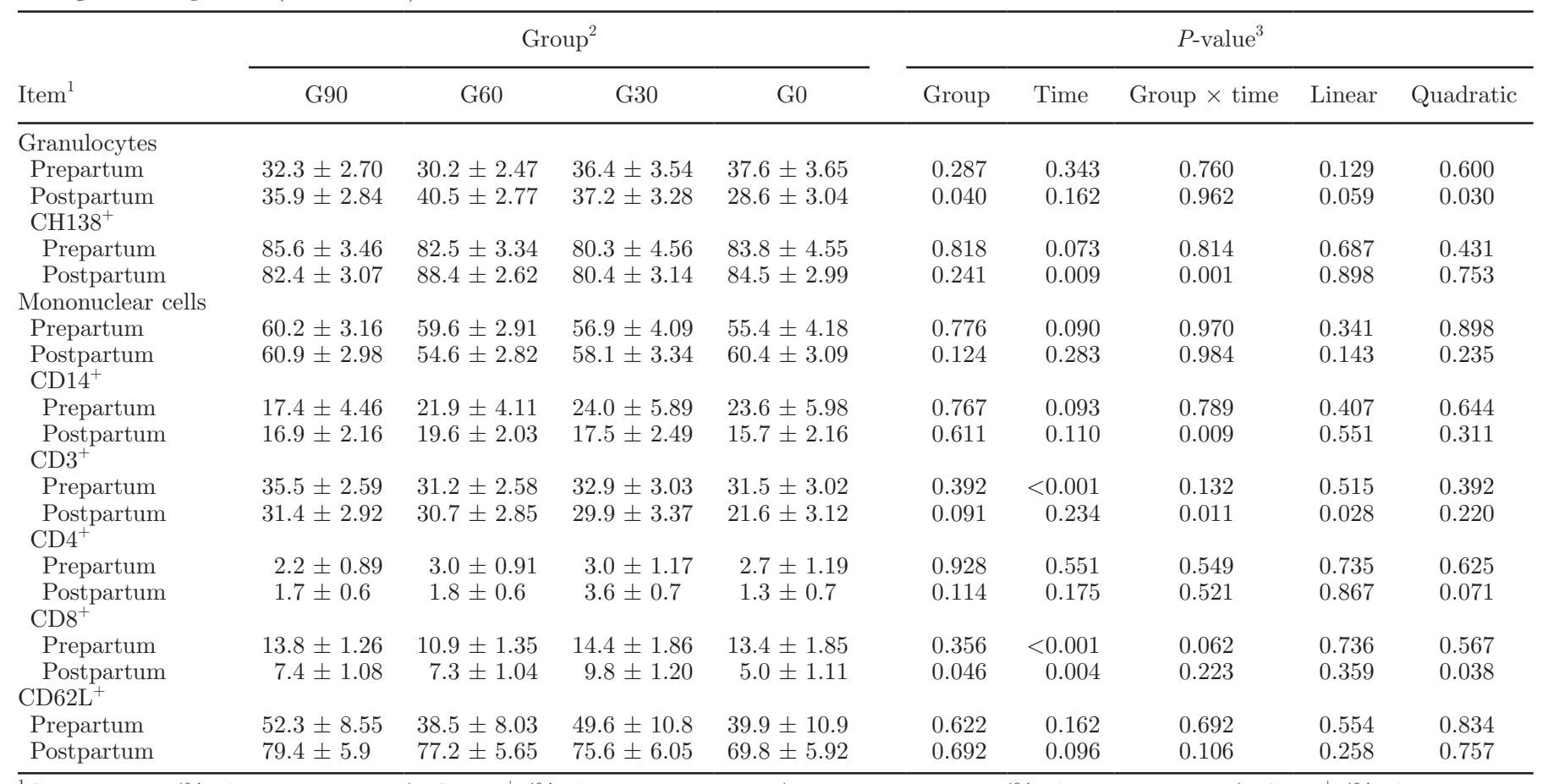

${ }^{1}$ Granulocytes (\% of total leukocytes); CH138 ${ }^{+}$(\% of total granulocytes); mononuclear cells (\% of total leukocytes); CD14 ${ }^{+}$(\% of total mononuclear cells); $\mathrm{CD}^{+}$(\% of total mononuclear cells); $\mathrm{CD}^{+}$(\% of total mononuclear cells); $\mathrm{CD}^{+}$(\% of total mononuclear cells); CD62L $\mathrm{L}^{+} \%$ of total leukocytes).

${ }^{2} \mathrm{G} 0=$ group 0 , cows did not receive whole raw soybeans (WS) throughout the prepartum period; G30, G60, and G90 = group that received diets containing WS from 30,60, and $90 \mathrm{~d}$ from the expected calving date, respectively.

${ }^{3}$ Probabilities for group, time (week), group by time, linear, and quadratic effects. 
period of supplementation on the immune response of cows in transition and early lactation is lacking. Thus, this study was designed to evaluate different durations of WS supplementation in the prepartum period on leukocytes population and phagocytic and ROS production of neutrophils and monocytes in dairy cows. Our hypothesis was that the longer the period of WS supplementation, the greater would be the improvements on leukocyte phagocytosis ability and ROS production in early lactating cows.

\section{MATERIALS AND METHODS}

This paper discusses the influence of different durations of WS supplementation in the prepartum period on measures of cellular immune function of transition and early lactating dairy cows. Other data from this experiment are described in a companion paper (Gardinal et al., 2018), including the nutrient intake and digestibility, energy balance, milk yield and FA profile, blood metabolites, and oocyte and embryo quality. This study was approved by the Ethics Committee of the School of Veterinary Medicine and Animal Science, University of Sao Paulo, and it was conducted at the Dairy Cattle Research Laboratory, Pirassununga, Brazil.

\section{Cows, Experimental Design, and Diets}

Detailed descriptions of cows, management, and diet compositions are shown in the study by Gardinal et al. (2018). Forty-four Holstein cows, in late lactation (20.3 $\pm 1.00 \mathrm{~kg} / \mathrm{d}$ milk yield, $332 \pm 26$ DIM) and with 90 $\mathrm{d}$ from the expected day of parturition, were used in a completely randomized design study, balanced for milk production and BCS of cows. Cows were dried off 60 $\mathrm{d}$ before the expected calving date. At the beginning of the study, 11 cows were assigned to each treatment; however, because of the occurrence of metabolic or infectious disorders not related to experimental treatments (3 abortions, 3 displaced abomasum, 3 foot disorders, and 4 dystocia), 13 cows were removed from the study, and only data of healthy cows were evaluated. Cows were distributed to one of the following groups $(\mathrm{G})$ : G90 (n = 8), G60 ( $\mathrm{n}=10), \mathbf{G 3 0}(\mathrm{n}=6)$ and G0 (control, $\mathrm{n}=7$ ). The groups were supplemented with a diet rich in $\mathrm{n}-6$ FA (12\% WS on a DM basis) from 90 ,

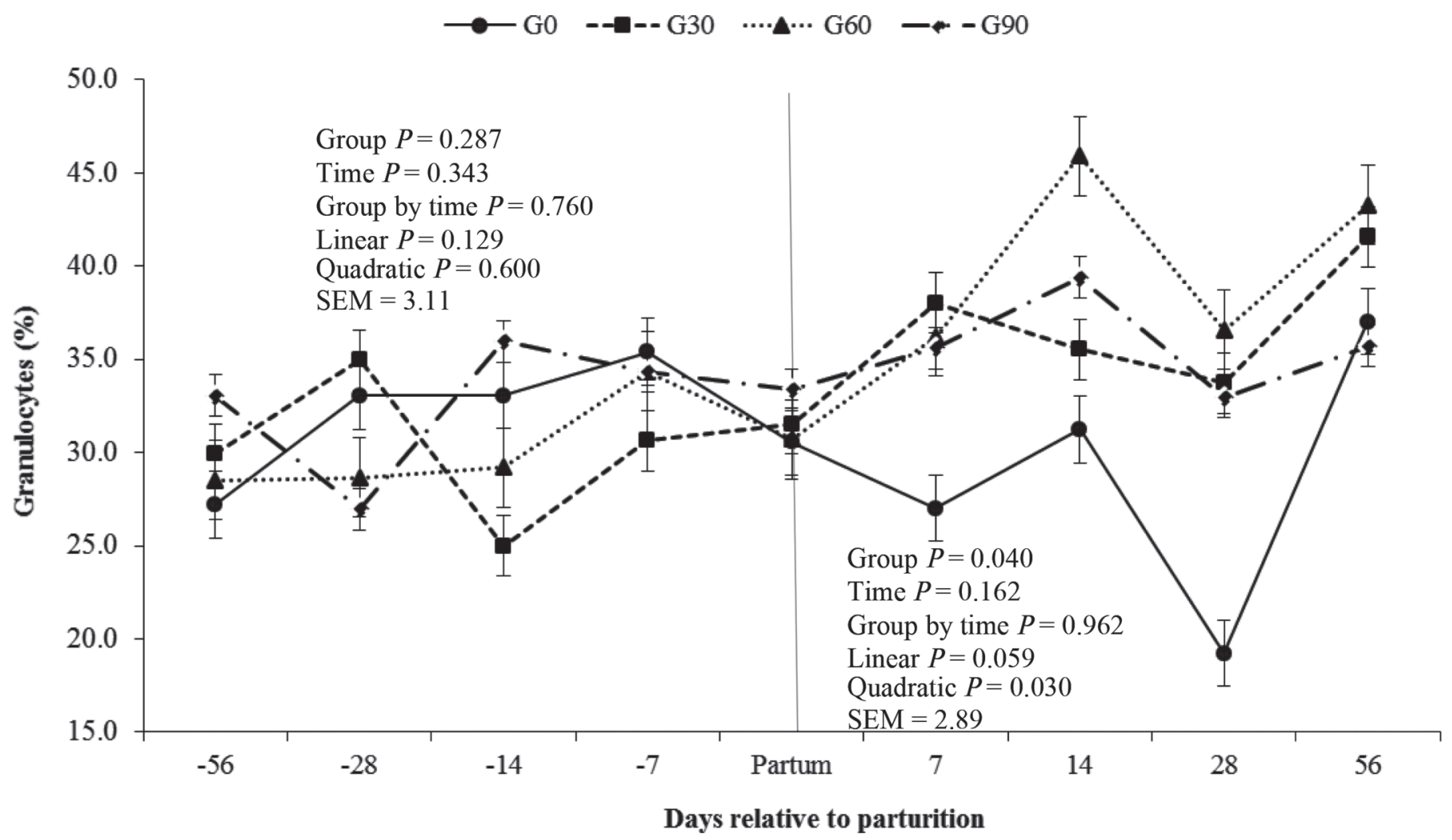

Figure 1. Blood granulocytes (\% of total leukocytes) of cows supplemented whole raw soybeans (WS) for different durations in the prepartum period. G0 $(\mathrm{n}=7)=$ cows fed a diet containing $12 \%$ WS after calving; G30 $(\mathrm{n}=6)$, G60 $(\mathrm{n}=10)$, and G90 ( $\mathrm{n}=8)=$ cows fed a diet containing $12 \%$ WS beginning at 30,60, and $90 \mathrm{~d}$ before the expected calving date, respectively. Error bars represent SE. 
60, 30 and $0 \mathrm{~d}$ relative to the expected calving date, respectively. After parturition, cows were fed a diet containing $12 \%$ of WS on a DM basis until 90 DIM.

\section{Immune Cell Phenotyping in Blood}

Whole blood (10 mL/cow) was collected by puncture of coccygeal vessels into sterile vacutainers $(\mathrm{BD}$ Vacutainer systems, Becton, Dickinson and Company, Franklin Lakes, NJ) containing anticoagulant solution (heparin). Blood samples $(10 \mathrm{~mL} / \mathrm{cow})$ were collected before the morning feeding ( $\mathrm{d}-56 \pm 2,-28 \pm 2,-14$ $\pm 2,-7 \pm 2$, partum, $7 \pm 2,14 \pm 2,28 \pm 2$, and 56 \pm 2 relative to parturition). Blood samples were transported on ice to the Department of Internal Medicine of the University of Sao Paulo.

Identification of leukocytes population was performed according to their cytoplasmic granularities (side scatter cells) and median fluorescence intensity (MFI) in a 2-step fluorescence immunolabeling protocol (Brown and Witter, 2000) using primary (targeting cell of interest) and secondary monoclonal antibodies with fluorescent probes (except for $\mathrm{CD} 62 \mathrm{~L}^{+}$cells). Cells were washed with PBS and incubated with primary monoclonal antibody for $30 \mathrm{~min}$ on ice. Then, $1 \mathrm{~mL}$ of PBS was added to the cell reconstitution and centrifuged at $250 \times g$ for $8 \mathrm{~min}$ at room temperature. Afterwards, secondary monoclonal antibody was added to the cell suspension and incubated on ice for $30 \mathrm{~min}$. Finally, cells were washed in PBS and analyzed by flow cytometry (20,000 leukocytes). Cell populations were determined using forward scatter and side scatter (Hart et al., 2011). For granulocytes and mononuclear cells, the calculation of the percentage of cells was based on the cell dispersion cytogram according to size (forward scatter) and cytoplasmic granularities (side scatter cells). For the neutrophil and mononuclear cells, the calculation of the percentage of cells bearing each marker was performed by subtracting the percentage of positive cells for detection antibody from the entire percentage of the cells classified as granulocytes and mononuclear cells, respectively.

For the CD62L $\mathrm{L}^{+}$cells, the calculation of the percentage of cells bearing each marker was performed by subtracting the percentage of positive cells for detection antibody from the entire percentage of the cells

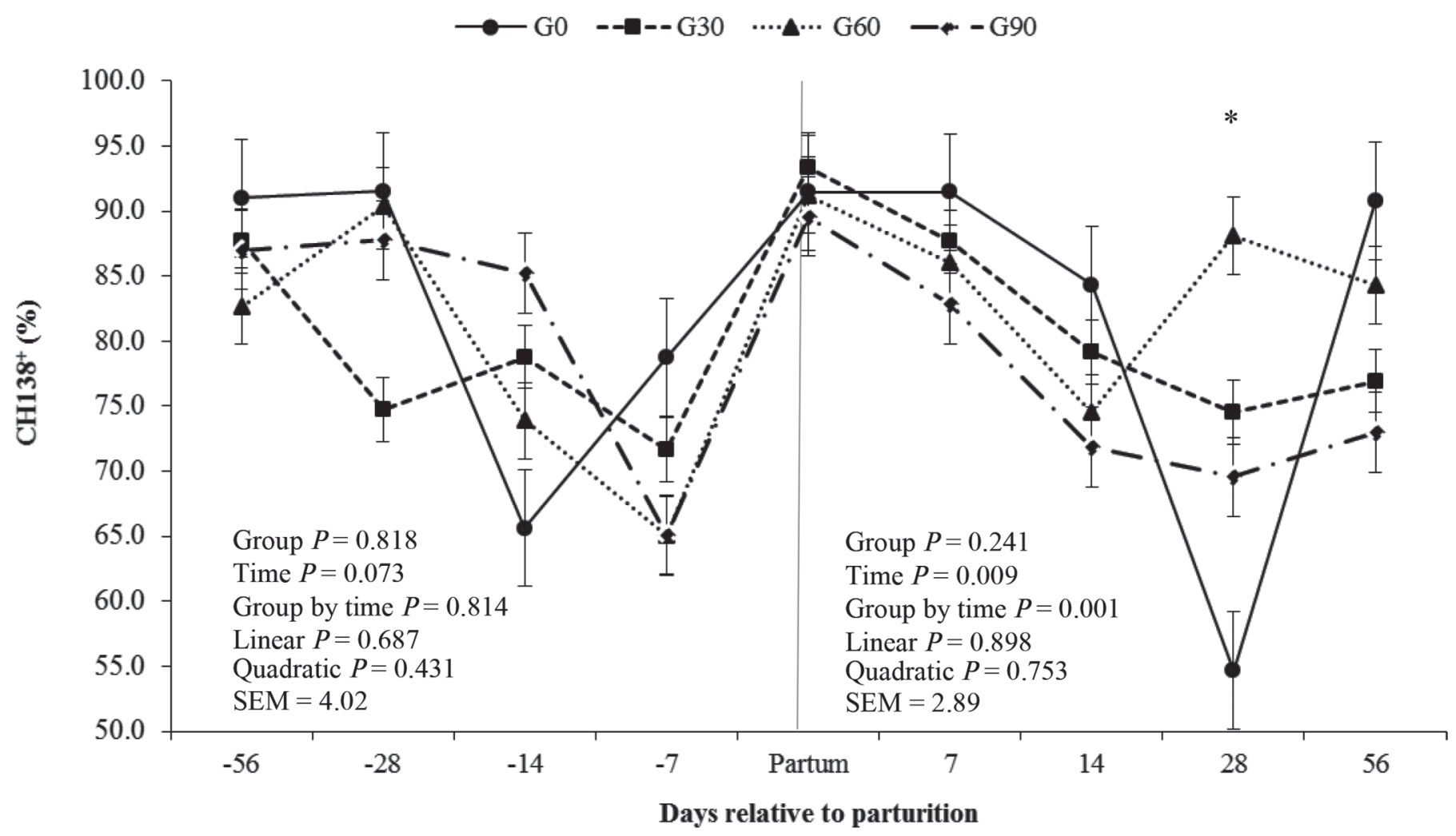

Figure 2. Percentage of granulocytes in blood expressing $\mathrm{CH} 138^{+}$molecules of cows supplemented whole raw soybeans (WS) for different durations in the prepartum period. G0 $(\mathrm{n}=7)=$ cows fed a diet containing $12 \%$ WS after calving; G30 $(\mathrm{n}=6)$, G60 (n = 10), and G90 $(\mathrm{n}=$ $8)=$ cows fed a diet containing $12 \%$ WS beginning at 30, 60, and $90 \mathrm{~d}$ before the expected calving date, respectively. Error bars represent SE; an asterisk indicates means in the same time point differ significantly. 
classified as granulocytes. For the T-lymphocytes, the calculation of the percentage of cells bearing each marker was performed by subtracting the percentage of positive cells for detection antibody from the cells classified as mononuclear cells. For T-helper cells and T-cytotoxic cells, the calculation of the percentage of cells bearing each marker was performed by subtracting the percentage of positive cells for detection antibody from the cells classified as T-lymphocytes cells. Pairs of antibodies used, amounts added, and their specificity are described by Blagitz et al. (2015).

\section{Function and ROS Production of $\mathrm{CH}_{138^{+}}$ Granulocytes and CD14 ${ }^{+}$Mononuclear Cells}

Assays for population quantification, for the assessment of the intracellular production of ROS, and for phagocytosis of blood monocytes and neutrophils were performed using flow cytometry (Hasui et al., 1989; Kampen et al., 2004a,b). The assays were performed in polypropylene tubes suitable for flow cytometry. To assess the basal intracellular ROS production, $100 \mu \mathrm{L}$ of total blood from each animal was added to each tube and incubated at $37^{\circ} \mathrm{C}$ for $30 \mathrm{~min}$ with $200 \mu \mathrm{L}$ of 0.3 $\mathrm{m} M$ 2,7c-dichlorofluorescein diacetate. To conduct the phagocytosis tests, $10 \mu \mathrm{L}$ of Staphylococcus aureus or Escherichia coli (both containing $3 \times 10^{5} / \mathrm{mL}$ ), labeled with Alexa 594 (Sigma-Aldrich, St. Louis, MO, cat. no. D6883), was added to those tubes.

After centrifuging $\left(250 \times g\right.$ for $8 \mathrm{~min}$ at $\left.4^{\circ} \mathrm{C}\right)$ and discarding the supernatant, $1 \mu \mathrm{L}$ of monoclonal primary antibody was added to the tubes according to the population to be identified, and the tubes were left standing at room temperature for $30 \mathrm{~min}$. After the incubation period, 1,000 $\mu \mathrm{L}$ of ice-cold PBS was added, and then another centrifugation $(250 \times g$ for 8 min at $4^{\circ} \mathrm{C}$ ) was performed. The supernatant was discarded, and $1 \mu \mathrm{L}$ of monoclonal secondary antibody was added to the tubes to label according to the population to be identified. The tubes were kept at room temperature in the dark for $30 \mathrm{~min}$. An additional washing was performed, and the samples were resuspended in $400 \mu \mathrm{L}$ of ice-cold PBS + BSA (0.1\%) and kept in the dark until they were read in a FACSCalibur flow cytometer (Becton Dickinson Immunocytometry Systems, San Diego, $\mathrm{CA}$ ). The cytometer was connected to a computer with

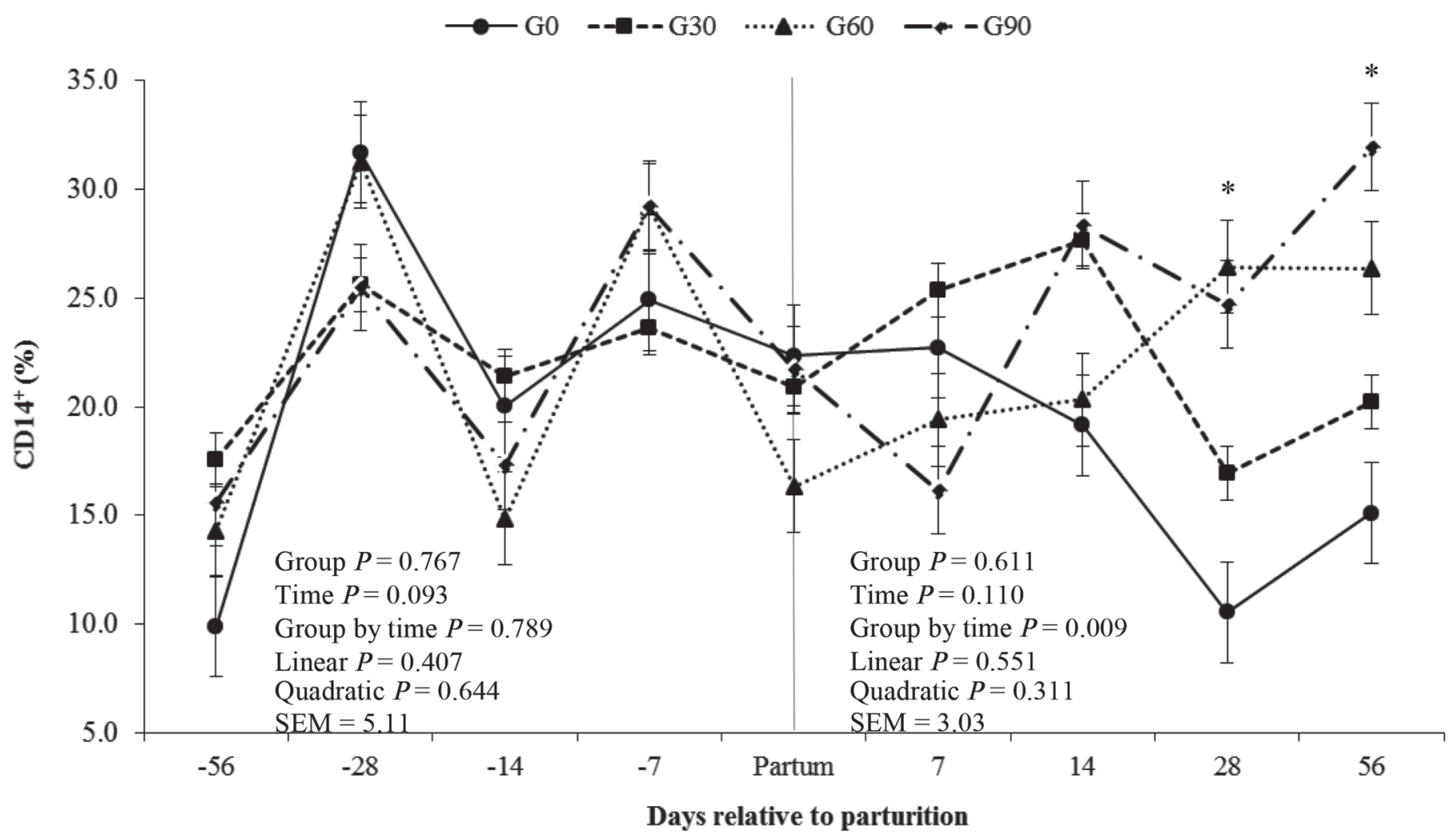

Figure 3. Percentage of mononuclear cells in blood expressing CD14 ${ }^{+}$molecules of cows supplemented whole raw soybeans (WS) for different durations in the prepartum period. G0 $(\mathrm{n}=7)=$ cows fed a diet containing $12 \%$ WS after calving; G30 $(\mathrm{n}=6)$, G60 $(\mathrm{n}=10)$, and G90 $(\mathrm{n}=$ $8)=$ cows fed a diet containing 12\% WS beginning at 30, 60, and $90 \mathrm{~d}$ before the expected calving date, respectively. Error bars represent SE; an asterisk indicates means in the same time point differ significantly. 
the software CellQuest (Becton Dickinson Immunocytometry Systems).

\section{Statistical Analysis}

Data were subjected to SAS (Version 9.1.3, 2004, SAS Institute Inc., Cary, NC), verifying the normality of residuals and homogeneity of variances by PROC UNIVARIATE. Outliers were removed to achieve normality of residuals when necessary. Data were analyzed by PROC MIXED as repeated measures (Littell et al., 2006) according to the model below:

$$
Y_{i j k}=\mu+G_{i}+T_{j}+G_{i} \times T_{j}+a_{k}+e_{i j k}
$$

where $Y_{i j k}=$ dependent variable; $\mu=$ overall mean; $G_{i}$ = fixed effect of group; $T_{j}=$ fixed effect of time; $G_{i}$ $\times T_{j}=$ fixed effect of group by time interaction; $a_{k}=$ random effect of animal; and $e_{i j k}=$ residual. The degrees of freedom were calculated according to the Satterthwaite's method (ddfm $=$ satterth). The covariance structure for each parameter was determined based on the smallest Akaike's information criterion values. Data from the first sampling date of blood parameters were added as a covariate adjustment to prepartum period statistical analysis. Data were independently analyzed for each period (pre- and postpartum) to establish the effect of duration of WS supplementation in the prepartum period on the early lactation. Differences among treatments were tested by polynomial simple regression. Significance was set at $P<0.05$.

\section{RESULTS}

\section{Immune Cell Phenotypes}

Duration of WS supplementation had a quadratic positive effect on the percentage of granulocytes in blood of postpartum cows $(P=0.030)$ but had no effect on the percentage of blood $\mathrm{CH} 138^{+}$cells (Table 1 ). Although the total percentage of mononuclear cells was not affected by the duration of WS supplementation, the percentage of $\mathrm{CD}^{+}$cells linearly increased $(P=$ $0.028)$ and the percentage of $\mathrm{CD} 8^{+}$cells exhibited a quadratic positive effect $(P=0.038)$ according to the period of WS supplementation. Neither time nor group by time effects $(P \geq 0.162)$ were observed for the total percentage of granulocytes in blood of cows (Figure 1).

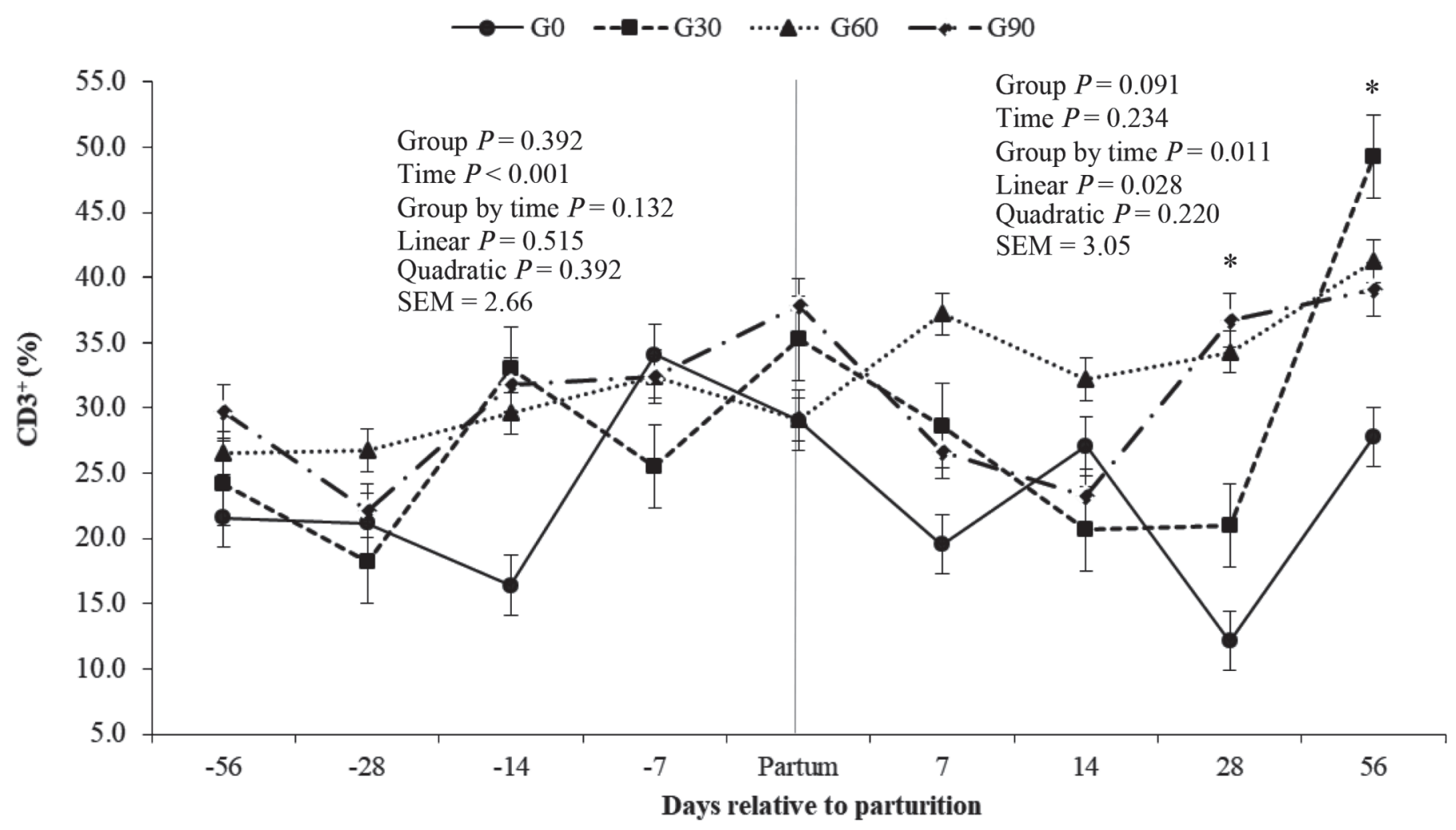

Figure 4. Percentage of mononuclear cells in blood expressing $\mathrm{CD}^{+}$molecules of cows supplemented whole raw soybeans (WS) for different durations in the prepartum period. G0 $(\mathrm{n}=7)=$ cows fed a diet containing 12\% WS after calving; G30 $(\mathrm{n}=6), \mathrm{G} 60(\mathrm{n}=10)$, and G90 $(\mathrm{n}=$ $8)$ = cows fed a diet containing $12 \%$ WS beginning at 30,60, and $90 \mathrm{~d}$ before the expected calving date, respectively. Error bars represent SE; an asterisk indicates means in the same time point differ significantly. 
A group by time interaction effect was noticed $(P=$ 0.001 ) for the percentage of $\mathrm{CH} 138^{+}$cells at $28 \mathrm{DIM}$ in cows (Figure 2). A group by time interaction effect was also observed $(P=0.009)$ for the percentage of CD14 ${ }^{+}$cells at 28 and 56 DIM (Figure 3 ). A group by time interaction effect $(P=0.011)$ was observed on the percentage of $\mathrm{CD}^{+}$cells in blood of cows at 28 and 56 DIM (Figure 4). Finally, a time effect was observed $(P$ $\leq 0.004)$ for the percentage of $\mathrm{CD}^{+}$cells in the preand postpartum periods of cows (Figure 5).

\section{Phagocytosis and ROS Production by $\mathrm{CH}_{138^{+}}$Granulocytes}

Duration of WS supplementation quadratically affected $(P=0.029)$ the percentage of $\mathrm{CH} 138^{+}$producing ROS when stimulated by $E$. coli in the postpartum period, wherein the highest value was found when WS supplementation began at $30 \mathrm{~d}$ from the expected calving date (Table 2). In addition, the length of WS supplementation linearly increased $(P=0.001)$ the ROS MFI of $\mathrm{CH}_{138^{+}}$after phagocytizing Staph. aureus in the postpartum period. No differences were found among experimental groups on the percentage of $\mathrm{CH} 138^{+}$cells able to phagocytize Staph. aureus or E. coli, but WS supplementation length linearly increased $(P=0.039)$ the phagocytosis MFI of $\mathrm{CH} 138^{+}$cells when stimulated by $E$. coli in the prepartum period. A time effect was found $(P \leq 0.009)$ in the pre- and postpartum periods for ROS MFI of $\mathrm{CH} 138^{+}$cells when stimulated by Staph. aureus (Figure 6). A time effect was noticed ( $P$ $=0.029)$ on phagocytosis MFI of $\mathrm{CH} 138^{+}$cells when stimulated by E. coli during the prepartum period (Figure 7).

\section{Phagocytosis and ROS Production by $\mathrm{CD} 14^{+}$Mononuclear Cells}

The length of WS supplementation linearly increased $(P \leq 0.048)$ the percentage of $\mathrm{CD} 14^{+}$cells producing ROS when stimulated by Staph. aureus and E. coli in the postpartum period (Table 3). Finally, no time and group by time interaction effects were observed for the percentage of $\mathrm{CD} 14^{+}$producing ROS when stimulated by Staph. aureus or E. coli (Figure 8 and Figure 9, respectively).

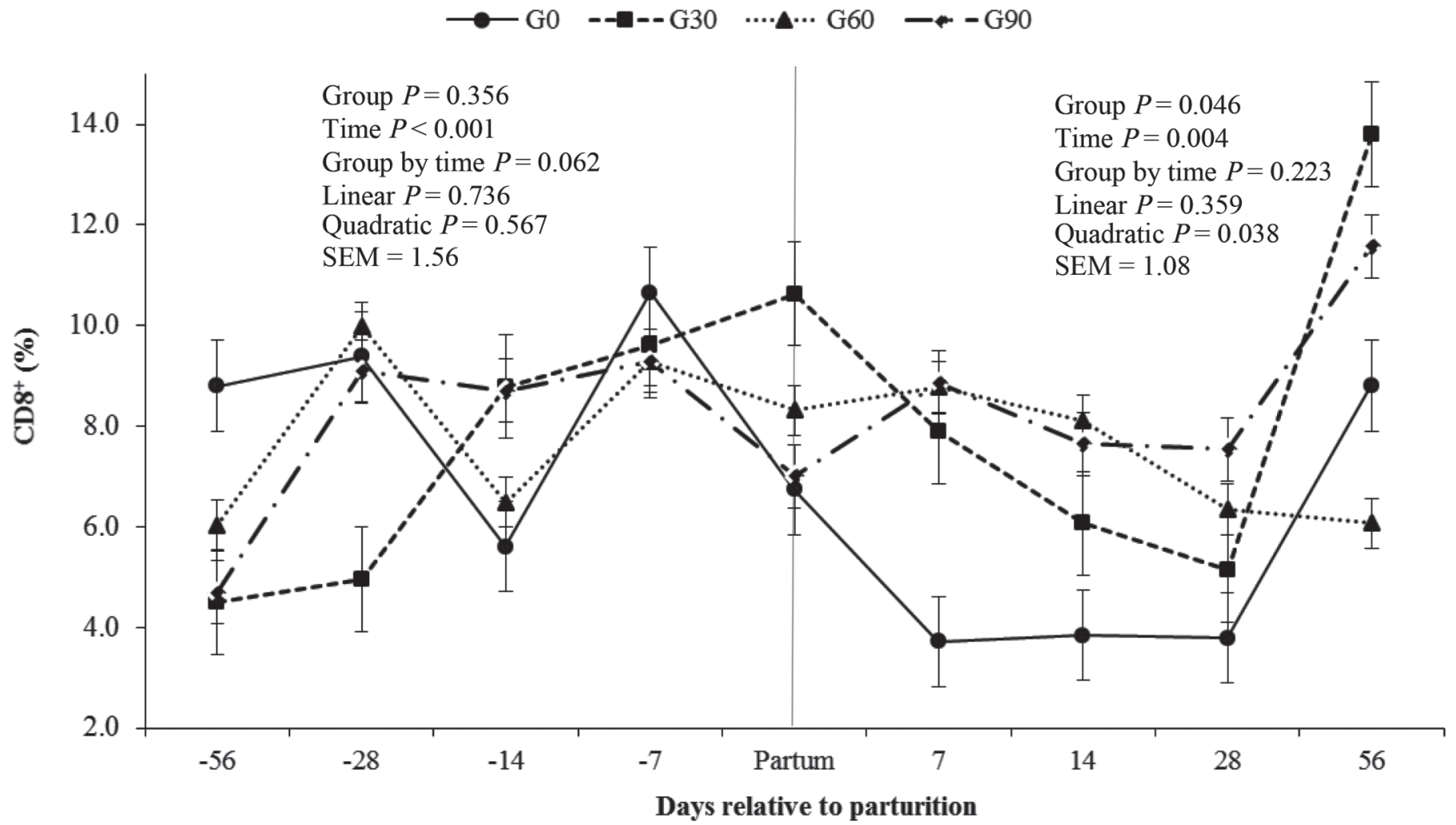

Figure 5. Percentage of mononuclear cells in blood expressing CD8 $8^{+}$molecules of cows supplemented whole raw soybeans (WS) for different durations in the prepartum period. G0 $(\mathrm{n}=7)=$ cows fed a diet containing $12 \%$ WS after calving; G30 $(\mathrm{n}=6)$, G60 $(\mathrm{n}=10)$, and G90 $(\mathrm{n}=$ $8)=$ cows fed a diet containing $12 \%$ WS beginning at 30,60, and $90 \mathrm{~d}$ before the expected calving date, respectively. Error bars represent SE. 


\section{DISCUSSION}

Whole raw soybean supplementation during the dry period and transition period increases abomasal flow of linoleic acid (Bettero et al., 2017) and linoleic acid content in milk of cows (Gandra et al., 2016b), suggesting that WS supplementation augments linoleic acid absorption in the gut of cows. Zachut et al. (2010) supplemented extruded flaxseed (rich in n-3 FA), an oilseed such as WS, to transition cows and found an increase in blood n-3 FA content. In addition, the current study showed that WS supplementation had a positive quadratic effect on cis-9,trans-11 C18:2 FA and total PUFA content in milk of cows, in which the highest values were found in G30, and the lowest values were found in G90 (Gardinal et al., 2018). Moreover, Barletta et al. (2016) concluded that supplying WS is a better strategy to protect PUFA against ruminal biohydrogenation in comparison with supplying calcium salts of FA to lactating cows. Thus, it is reasonable to consider the provision of WS, or other oilseeds, as a way to increase blood PUFA concentration in dairy cows.
Positive effects of WS supplementation to transition cows on measures of immune system were reported in literature by Gandra et al. (2016a), but these authors provided WS from $35 \mathrm{~d}$ of the expected calving date to 84 DIM. In this experiment, we evaluated different durations of WS supplementation including $-90,-60$, -30 , and $0 \mathrm{~d}$ relative to the calving date until 90 DIM. Rumen microbiota of cows fed PUFA for longer periods has shown enhancements of biohydrogenation efficiency (Hobson and Stewart, 2012), which affects linoleic acid and its products of biohydrogenation availability in the intestine.

Changes in leukocyte population profile were observed when supplementing WS in the prepartum period to dairy cows. Blood granulocyte percentage increased when supplementing WS beginning at 30 or 60 d before the expected calving date, but no differences were detected in neutrophils percentage. Granulocytes in blood are composed of eosinophils and basophils, besides neutrophils. The role of basophils is still not clear, but they are thought to play a role in host defense against parasites (Stone et al., 2010). The activation of basophils leads to IL-4 and IL-13 release, which stimu-

Table 2. CH138 ${ }^{+}$granulocyte production of reactive oxygen species (ROS) and phagocytic responses of dairy cows to different periods of whole raw soybean supplementation (mean $\pm \mathrm{SD}$ )

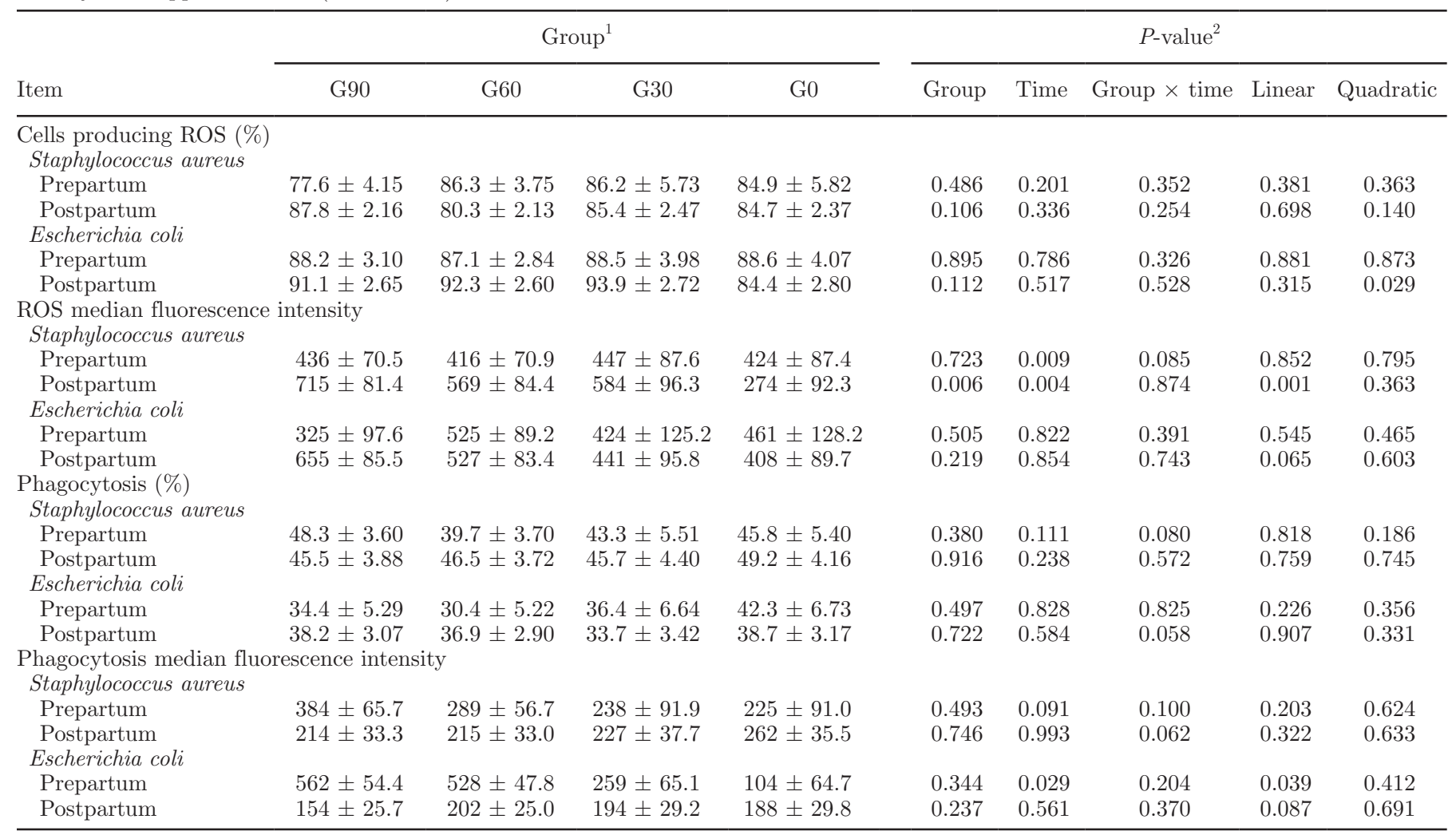

${ }^{1} \mathrm{G} 0=$ group 0 , cows did not receive whole raw soybeans (WS) throughout the prepartum period; G30, G60, and G90 = group that received diets containing WS from 30,60, and $90 \mathrm{~d}$ from the expected calving date, respectively.

${ }^{2}$ Probabilities for group, time (week), group by time, linear, and quadratic effects. 
lates the differentiation of naïve T-cells and triggers allergic inflammation, respectively. Eosinophils, when activated, release several pro-inflammatory molecules, such as eicosanoids, cytokines, and granule-stored cationic proteins; eosinophils are usually elevated in peripheral blood during allergic reactions and helminthic infections (Hogan et al., 2008). The duration of WS supplementation did not affect granulocyte population, because neutrophils accounted for over $80 \%$ of total granulocytes in peripheral blood of cows in this study.

The longer was the period of WS supplementation, the higher was the percentage of blood $\mathrm{CD}^{+}$mononuclear cells (T-lymphocytes) and $\mathrm{CD}^{+}$mononuclear cells (Tcytotoxic) in the postpartum period. T-lymphocytes may respond to a stimulus and further differentiate in subsets including T-helper or T-cytotoxic cells. Tcells play a role in the adaptive immune system by mediating certain attributes such as specific, diversity, memory, and recognition of self and non-self molecules (Sordillo, 2016). Activation of T-helper cells results in cytokines production with a range of immune responses (Sordillo and Streicher, 2002), and T-cytotoxic $\left(\mathrm{CD} 8^{+}\right)$ cells destroy altered self cells. We found an increase in percentage of blood $\mathrm{CD}^{+}$cells, but the literature frequently reports that PUFA supplementation causes alterations in lymphocyte membranes associated with decreased T-cell proliferation in humans (Curi et al., 1993; Larbi et al., 2005). Data are lacking in the literature regarding PUFA supplementation on lipid membrane composition in lymphocytes of bovine, and thus, outcomes may differ from those expected for humans. The different responses may be related to the dietary concentration of linoleic acid supplied, because linoleic acid is toxic to T-cells when provided in high concentration (Cury-Boaventura et al., 2006), but linoleic acid can induce proliferation when supplied in nontoxic concentrations (Ioan-Facsinay et al., 2013).

In addition, the lack of WS effects in the prepartum period and their positive responses in the postpartum period are partially related to blood NEFA concentration of the cow. Whereas cows supplemented with WS before the partum date (G90, G60, and G30) exhibited an average blood NEFA concentration of $0.42 \mathrm{mmol} / \mathrm{L}$ in the postpartum period, cows in G0 had a blood

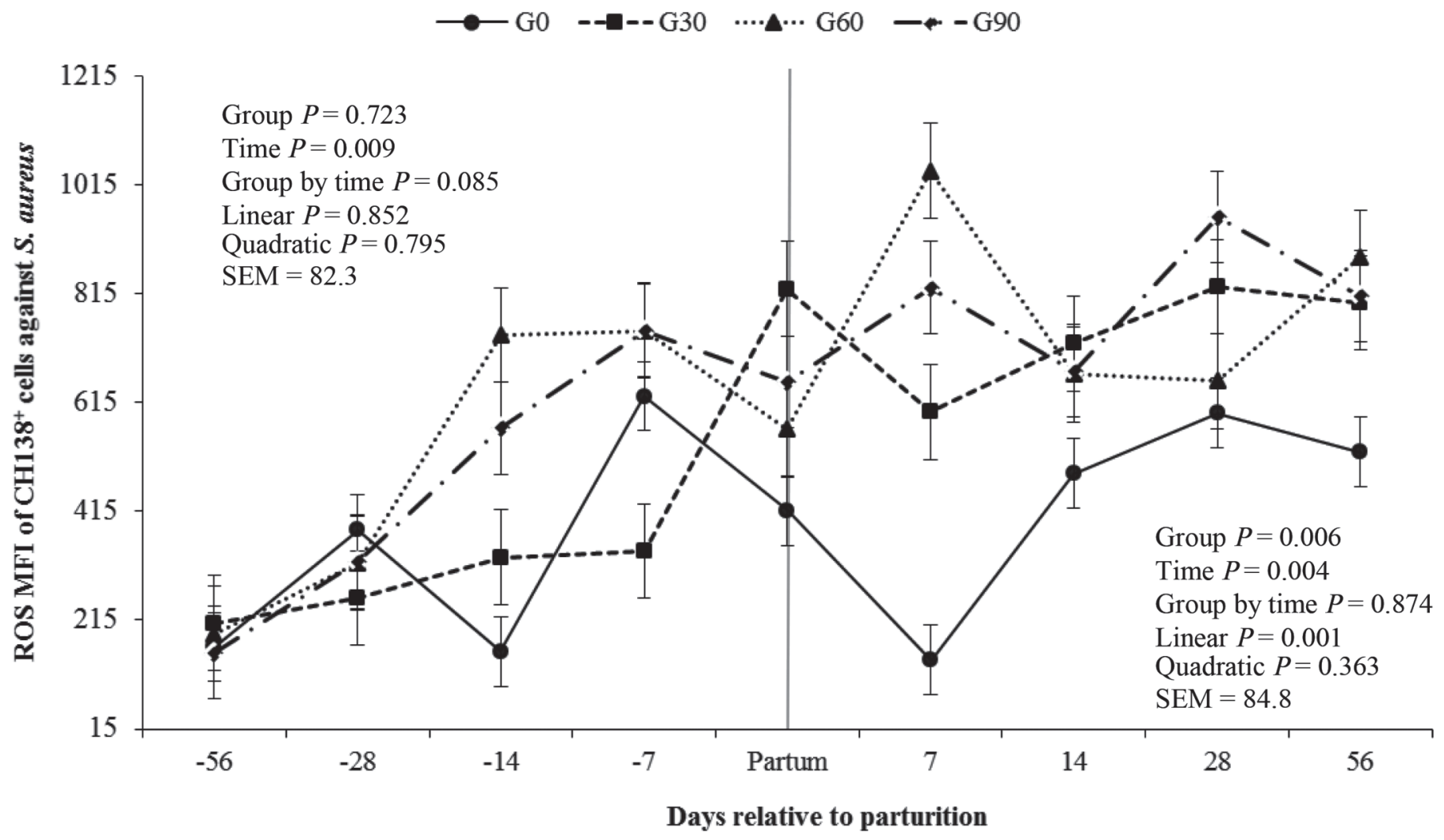

Figure 6. Median fluorescence intensity (MFI) of the reactive oxygen species (ROS) production in blood CH138 $8^{+}$granulocytes when stimulated by Staphylococcus aureus in cows supplemented whole raw soybeans $(\mathrm{WS})$ for different durations in the prepartum period. G0 $(\mathrm{n}=7)=$ cows fed a diet containing 12\% WS after calving; G30 $(\mathrm{n}=6), \mathrm{G} 60(\mathrm{n}=10)$, and G90 $(\mathrm{n}=8)=$ cows fed a diet containing $12 \%$ WS beginning at 30,60, and $90 \mathrm{~d}$ before the expected calving date, respectively. Error bars represent SE. 
NEFA concentration of $0.51 \mathrm{mmol} / \mathrm{L}$ (Gardinal et al., 2018). In vitro studies have reported that an equivalent NEFA concentration of periparturient cows in vivo decreases peripheral blood mononuclear cell proliferation (Ster et al., 2012).

The innate immune response is primarily mediated by neutrophil and macrophage phagocytosis capacity and ROS production. Neutrophils $\left(\mathrm{CH} 138^{+}\right.$granulocytes) are the first line of cellular defense against antigens. Neutrophils contain numerous cytoplasmic ROS granules to destroy bacteria, store large amounts of glycogen as an energy source, and have a convoluted surface that facilitates phagocytosis and intracellular vacuole formation (Paape et al., 2003). Researchers have demonstrated that WS supplementation to transition cows can increase the capacity of neutrophils to engulf Staph. aureus in in vitro challenges (Gandra et al., 2016a). In the current study, we demonstrated that the duration of WS supplementation increased the ROS MFI of blood neutrophils phagocytizing Staph. aureus in early lactating cows. In other words, WS supplementation likely increases the capacity of neutrophils to de- stroy Staph. aureus. Further, we also demonstrated that WS supplementation increased the phagocytosis MFI of neutrophils after phagocytizing E. coli in prepartum cows. This means that WS supplementation increases the capacity of neutrophils to engulf $E$. coli in the prepartum period. Therefore, the results of phagocytosis and oxidative burst suggest that longer periods of WS supplementation (notably from $90 \mathrm{~d}$ of the expected calving date) positively influence the response and activation of neutrophils in both the pre- and postpartum periods.

The exact mechanism by which WS supplementation may enhance blood neutrophils function is still unknown. One potential mechanism may be related to linoleic acid conversion to arachidonic acid, with consequent production of pro-inflammatory mediators such as IL-1, IL-2, IL-6, tumor necrosis factor $\alpha$, and IFN- $\gamma$ (Yaqoob and Calder, 1995; Beutler et al., 2003; Greco et al., 2015). Silvestre et al. (2011) reported that the n-6 FA content in the membrane of neutrophils tended to increase after supplementing safflower oil (linoleic acid source, $63.6 \mathrm{~g} / 100 \mathrm{~g}$ of FA) to periparturient cows.

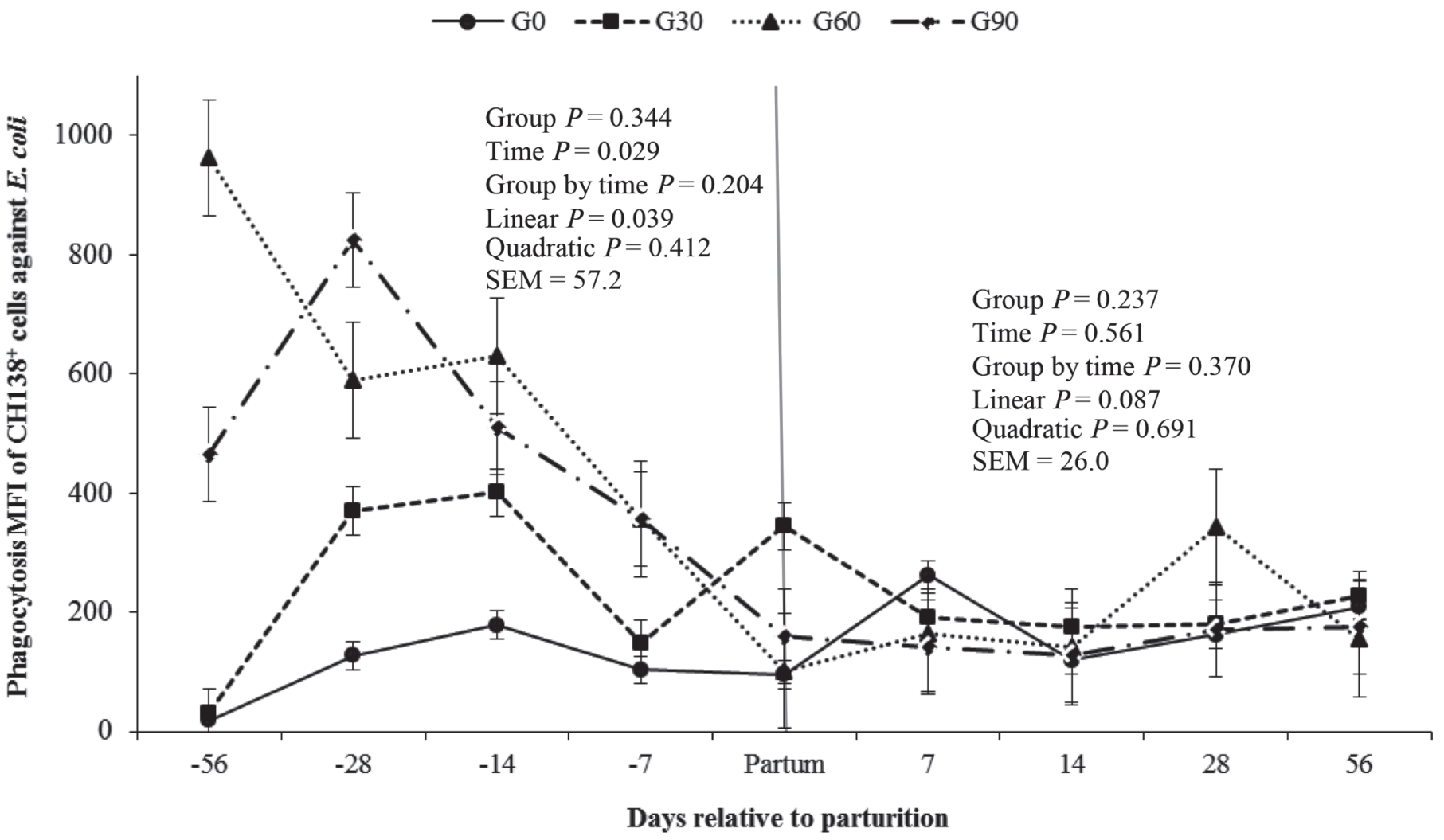

Figure 7. Median fluorescence intensity (MFI) of the phagocytosis in blood CH138 ${ }^{+}$granulocytes when stimulated by Escherichia coli in cows supplemented whole raw soybeans (WS) for different durations in the prepartum period. G0 $(\mathrm{n}=7)=$ cows fed a diet containing $12 \%$ WS after calving; G30 $(\mathrm{n}=6), \mathrm{G} 60(\mathrm{n}=10)$, and G90 $(\mathrm{n}=8)=$ cows fed a diet containing $12 \%$ WS beginning at 30,60 , and $90 \mathrm{~d}$ before the expected calving date, respectively. Error bars represent SE. 
Increased proportions of $n-6$ and n- 3 FA in neutrophil and monocyte membranes were positively correlated with phagocytosis capacity and ROS production in humans (Kew et al., 2003). Changes in FA profile of the leukocyte membrane may also alter the gene expression of lipid mediators related to inflammation (Calder, 2006). Among the lipid mediators, eicosanoids (prostaglandins, prostacyclin, leukotrienes, lipoxin, and thromboxane) are known regulators of acute and chronic inflammation responses, activating endothelial cells and leukocyte populations (Contreras and Sordillo, 2011). Further, CLA isomers such as cis-9,trans-11 C18:2 FA have improved the cellular immunity in pigs by increasing the cytotoxic potential of peripheral blood lymphocytes (Bassaganya-Riera et al., 2001).

The duration of WS supplementation increased the percentage of monocytes producing ROS against Staph. aureus and E. coli during the postpartum period of cows, without enhancing ROS production inside the cells and without affecting the ability of monocytes to engulf bacteria. Our findings suggest that WS supplementation during the prepartum period does not in- crease the capacity of macrophages to destroy bacteria. These results support previous findings where cows supplemented with WS in the pre- and postpartum periods did not show differences in monocyte phagocytosis capacity against Staph. aureus, whereas WS supplementation increased the percentage of phagocytic monocytes (Gandra et al., 2016a).

We need to stress that positive effects on the immune system may also be related to the greater blood concentration of trans FA and CLA (not measured in this study), because they are products of partial biohydrogenation of lipids in WS. Although it is difficult to attribute the positive effects of WS supplementation on the immune system to specific FA, this study clearly demonstrated that WS supplementation modulates the immune system of transition cows. Finally, note that although WS supplementation in the pre- and postpartum periods modulated the immune system of cows, this study did not demonstrate effects of WS supplementation on productive performance, energy balance, and blood NEFA concentration in early lactating cows (Gardinal et al., 2018); thus, the influences of WS sup-

Table 3. CD14 ${ }^{+}$mononuclear cell production of reactive oxygen species (ROS) and phagocytic responses of dairy cows to different periods of whole raw soybean supplementation (mean $\pm \mathrm{SD}$ )

\begin{tabular}{|c|c|c|c|c|c|c|c|c|c|}
\hline Item & \multicolumn{4}{|c|}{ Group $^{1}$} & \multicolumn{5}{|c|}{$P$-value ${ }^{2}$} \\
\hline \multicolumn{10}{|c|}{ Cells producing ROS (\%) } \\
\hline Prepartum & $52.1 \pm 5.30$ & $47.6 \pm 5.02$ & $46.7 \pm 6.69$ & $43.5 \pm 6.89$ & 0.788 & 0.372 & 0.265 & 0.338 & 0.924 \\
\hline Postpartum & $64.8 \pm 4.18$ & $56.6 \pm 4.12$ & $63.2 \pm 4.74$ & $45.5 \pm 6.59$ & 0.012 & 0.056 & 0.761 & 0.010 & 0.284 \\
\hline \multicolumn{10}{|c|}{ Escherichia coli } \\
\hline \multicolumn{10}{|c|}{ Staphylococcus aureus } \\
\hline Prepartum & $86.3 \pm 21.0$ & $91.0 \pm 20.1$ & $80.3 \pm 24.1$ & $68.6 \pm 26.7$ & 0.918 & 0.711 & 0.076 & 0.549 & 0.725 \\
\hline Postpartum & $138 \pm 24.2$ & $120 \pm 24.2$ & $164 \pm 27.6$ & $72.0 \pm 26.0$ & 0.104 & 0.026 & 0.584 & 0.179 & 0.152 \\
\hline \multicolumn{10}{|c|}{ Escherichia coli } \\
\hline Prepartum & $66.7 \pm 18.5$ & $83.3 \pm 16.9$ & $89.7 \pm 23.0$ & $81.6 \pm 1.39$ & 0.864 & 0.507 & 0.130 & 0.587 & 0.553 \\
\hline Postpartum & $105 \pm 16.7$ & $76.6 \pm 17.0$ & $119 \pm 18.9$ & $78.1 \pm 17.3$ & 0.266 & 0.005 & 0.266 & 0.614 & 0.725 \\
\hline Prepartum & $38.1 \pm 5.75$ & $44.3 \pm 5.59$ & $43.3 \pm 7.05$ & $53.9 \pm 6.99$ & 0.396 & 0.435 & 0.701 & 0.115 & 0.741 \\
\hline Postpartum & $48.6 \pm 3.31$ & $48.6 \pm 3.31$ & $44.0 \pm 3.85$ & $47.3 \pm 3.57$ & 0.717 & 0.049 & 0.321 & 0.444 & 0.543 \\
\hline \multicolumn{10}{|c|}{ Phagocytosis median fluorescence intensity } \\
\hline \multicolumn{10}{|c|}{ Staphylococcus aureus } \\
\hline Prepartum & $50.8 \pm 8.42$ & $43.6 \pm 7.12$ & $41.5 \pm 9.51$ & $30.1 \pm 9.61$ & 0.094 & 0.463 & 0.632 & 0.086 & 0.672 \\
\hline Postpartum & $52.2 \pm 5.50$ & $41.7 \pm 5.77$ & $45.3 \pm 5.93$ & $43.8 \pm 6.12$ & 0.582 & 0.057 & 0.188 & 0.412 & 0.444 \\
\hline \multicolumn{10}{|c|}{ Escherichia coli } \\
\hline Prepartum & $52.7 \pm 11.3$ & $57.5 \pm 9.55$ & $34.7 \pm 15.7$ & $35.7 \pm 15.6$ & 0.550 & 0.340 & 0.341 & 0.296 & 0.894 \\
\hline Postpartum & $66.4 \pm 10.6$ & $61.8 \pm 11.06$ & $62.2 \pm 11.7$ & $70.7 \pm 12.5$ & 0.947 & 0.081 & 0.080 & 0.798 & 0.573 \\
\hline
\end{tabular}

${ }^{1} \mathrm{G} 0=$ group 0 , cows did not receive whole raw soybeans (WS) throughout the prepartum period; G30, G60, and G90 = group that received diets containing WS from 30,60, and $90 \mathrm{~d}$ from the expected calving date, respectively.

${ }^{2}$ Probabilities for group, time (week), group by time, linear, and quadratic effects. 


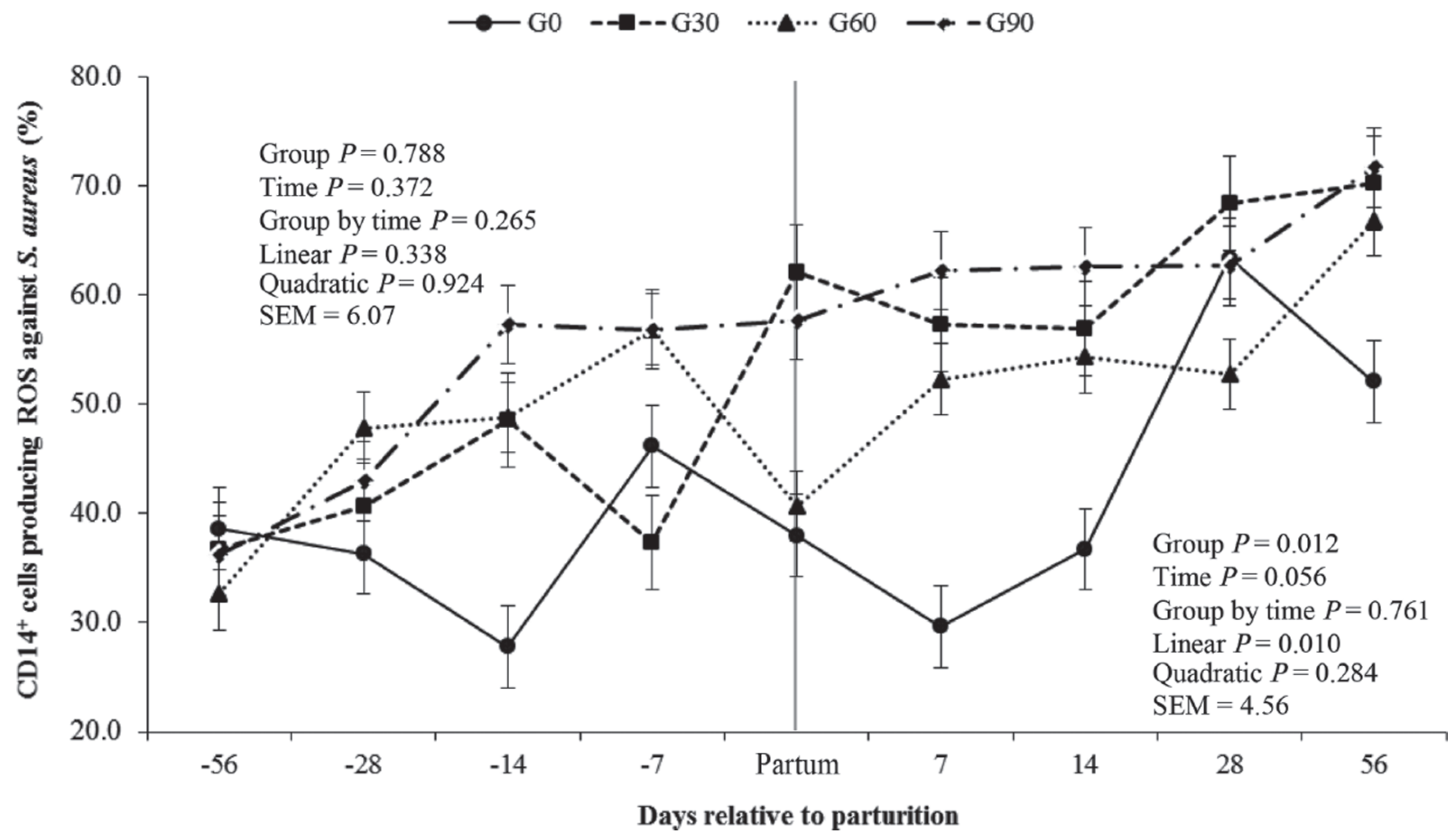

Figure 8. Percentage of $\mathrm{CD} 14^{+}$mononuclear cells producing reactive oxygen species (ROS) when stimulated by Staphylococcus aureus in cows supplemented whole raw soybeans (WS) for different durations in the prepartum period. G0 $(\mathrm{n}=7)=$ cows fed a diet containing $12 \%$ WS after calving; G30 $(\mathrm{n}=6)$, G60 $(\mathrm{n}=10)$, and G90 $(\mathrm{n}=8)=$ cows fed a diet containing $12 \%$ WS beginning at 30, 60 , and $90 \mathrm{~d}$ before the expected calving date, respectively. Error bars represent SE.

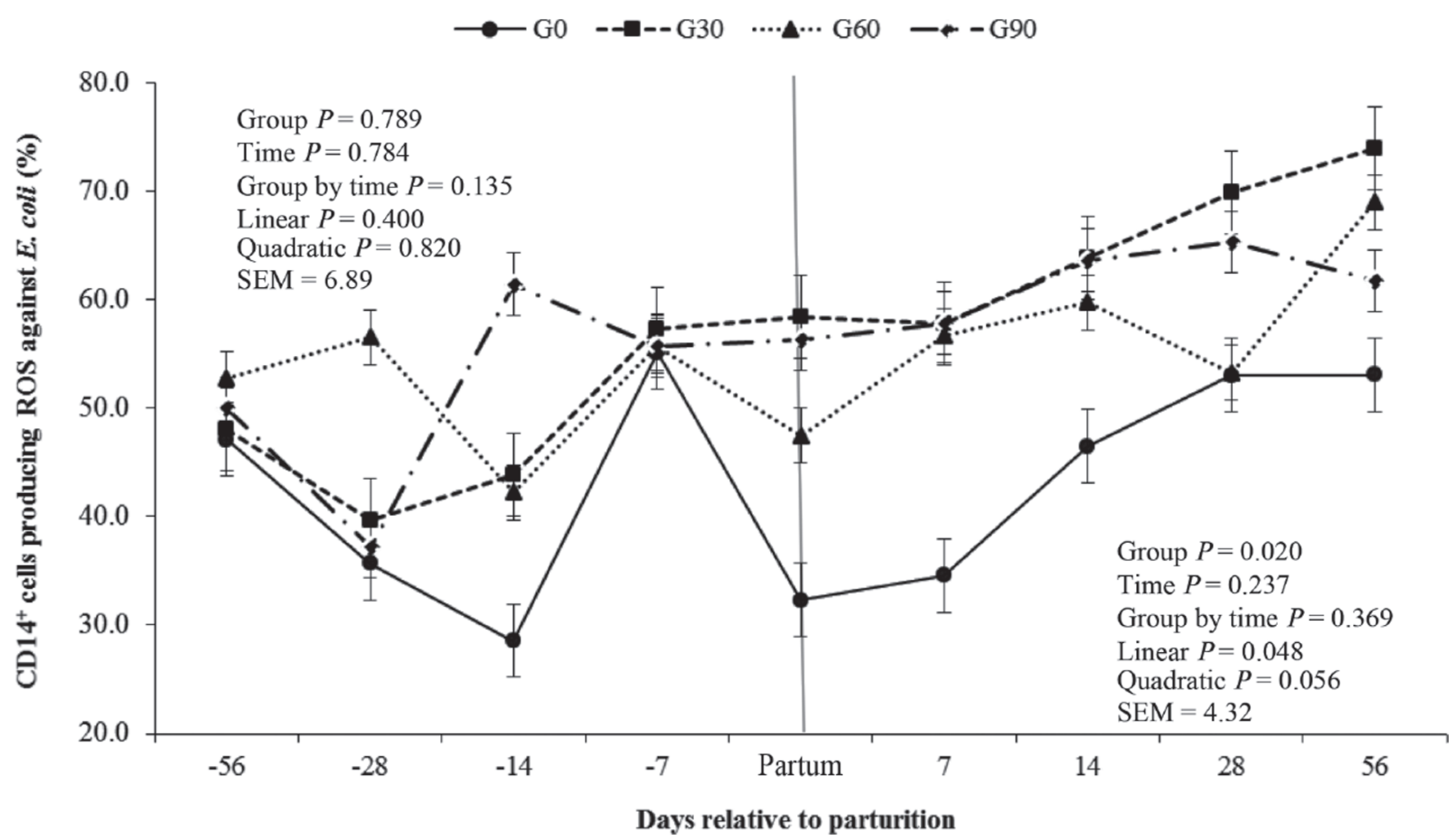

Figure 9. Percentage of $\mathrm{CD}_{1} 4^{+}$mononuclear cells producing reactive oxygen species (ROS) when stimulated by Escherichia coli in cows supplemented whole raw soybeans (WS) for different durations in the prepartum period. G0 $(\mathrm{n}=7)=$ cows fed a diet containing $12 \%$ WS after calving; G30 $(\mathrm{n}=6)$, G60 $(\mathrm{n}=10)$, and G90 $(\mathrm{n}=8)=$ cows fed a diet containing $12 \%$ WS beginning at 30, 60, and 90 d before the expected calving date, respectively. Error bars represent SE. 
plementation on immune measures are related to the period of supplementation and FA profile metabolized by cows.

\section{CONCLUSIONS}

Different periods of WS supplementation, notably 60 and $30 \mathrm{~d}$ from the expected calving date, influenced the leukocyte population of cows by increasing the percentage of blood granulocytes, T-lymphocytes, and T-cytotoxic cells in the postpartum period. Furthermore, longer periods of WS supplementation enhanced neutrophil activity supported by an increase in ROS production against Staph. aureus and an augment in the capacity to phagocytize E. coli in the postpartum period. In general, WS supplementation starting at 90 $\mathrm{d}$ from the expected calving date altered the leukocyte population and improved neutrophil immune response in the postpartum period of dairy cows. Whole raw soybean supplementation during the prepartum period may be a strategy to improve the immune status of early lactating cows and potentially decrease infectious diseases in this period.

\section{ACKNOWLEDGMENTS}

The authors acknowledge the University of Sao Paulo and Dairy Cattle Research Laboratory for providing the infrastructure and staff necessary for this study. In addition, the authors express appreciation to the Sao Paulo Research Foundation for financial support (grant \#2012/02360-1).

\section{REFERENCES}

Barletta, R. V., J. R. Gandra, V. P. Bettero, C. E. Araujo, T. A. Del Valle, G. F. Almeida, E. F. Jesus, R. D. Mingoti, B. C. Benevento, J. E. Freitas Jr., and F. P. Renno. 2016. Ruminal biohydrogenation and abomasal flow of fatty acids in lactating cows: Oilseed provides ruminal protection for fatty acids. Anim. Feed Sci. Technol. 219:111-121.

Bassaganya-Riera, J., R. Hontecillas, D. R. Zimmerman, and M. J. Wannemuehler. 2001. Dietary conjugated linoleic acid modulates phenotype and effector function of porcine CD8+ lymphocytes. J. Nutr. 131:2370-2377.

Bettero, V. P., T. A. Del Valle, R. V. Barletta, C. E. Araújo, E. Ferreira de Jesus, G. F. Almeida, C. S. Takiya, F. Zanferari, P. G. Paiva, J. E. Freitas Jr., and F. P. Rennó. 2017. Use of protected fat sources to reduce fatty acid biohydrogenation and improve abomasal flow in dry dairy cows. Anim. Feed Sci. Technol. 224:30-38.

Beutler, B., K. Hoebe, X. Du, and R. J. Ulevitch. 2003. How we detect microbes and respond to them: The toll-like receptors and their transducers. J. Leukoc. Biol. 74:479-485.

Blagitz, M. G., F. N. Souza, C. F. Batista, L. F. Azevedo, N. R. Benites, P. A. Melville, S. A. Diniz, M. X. Silva, J. P. A. Haddad, M. B. Heinnemann, M. O. P. Cerqueira, and A. M. M. P. Della Libera. 2015. The neutrophil function and lymphocyte profile of milk from bovine mammary glands infected with Streptococcus dysgalactiae. J. Dairy Res. 82:460-469.
Brown, M., and C. Witter. 2000. Flow cytometry: Principles and clinical applications in hematology. Clin. Chem. 46:1221-1229.

Cai, T. Q., P. G. Weston, L. A. Lund, B. Brodie, D. J. McKenna, and W. C. Wagner. 1994. Association between neutrophil functions and periparturient disorders in cows. Am. J. Vet. Res. 55:934-943.

Calder, P. C. 2006. Polyunsaturated fatty acids and inflammation. Prostaglandins Leukot. Essent. Fatty Acids 75:197-202.

Calder, P. C. 2012. Long-chain fatty acids and inflammation. Proc. Nutr. Soc. 71:284-289.

Carroll, J. A., and N. E. Forsberg. 2007. Influence of stress and nutrition on cattle immunity. Vet. Clin. North Am. Food Anim. Pract. 23:105-149.

Contreras, G. A., and L. M. Sordillo. 2011. Lipid mobilization and inflammatory responses during the transition period of dairy cows. Comp. Immunol. Microbiol. Infect. Dis. 34:281-289.

Curi, R., J. A. Bond, P. C. Calder, and E. A. Newsholme. 1993. Propionate regulates lymphocyte proliferation and metabolism. Gen. Pharmacol. 24:591-597.

Cury-Boaventura, M. F., R. Gorjao, T. M. Lima, P. Newsholme, and R. Curi. 2006. Comparative toxicity of oleic and linoleic acid on human lymphocytes. Life Sci. 78:1448-1456.

Eger, M., J. Horn, J. Hussen, H. J. Schuberth, M. Scharf, U. Meyer, S. Danicke, H. Bostedt, and G. Breves. 2017. Effects of dietary CLA supplementation, parity and different concentrate levels before calving on immunoglobulin G1, G2 and M concentrations in dairy cows. Res. Vet. Sci. 114:287-293.

Gandra, J. R., R. V. Barletta, R. D. Mingoti, L. C. Verdurico, J. E. Freitas Jr., L. J. Oliveira, C. S. Takiya, J. R. Kfoury Jr., M. C. Wiltbank, and F. P. Renno. 2016a. Effects of whole flaxseed, raw soybeans, and calcium salts of fatty acids on measures of cellular immune function of transition dairy cows. J. Dairy Sci. 99:45904606.

Gandra, J. R., R. D. Mingoti, R. V. Barletta, C. S. Takiya, L. C. Verdurico, J. E. Freitas Jr., P. G. Paiva, E. F. Jesus, G. D. Calomeni, and F. P. Rennó. 2016b. Effects of flaxseed, raw soybeans and calcium salts of fatty acids on apparent total tract digestibility, energy balance and milk fatty acid profile of transition cows. Animal 10:1303-1310.

Gardinal, R., G. D. Calomeni, F. Zanferari, T. H. A. Vendramini, C. S. Takiya, T. A. Del Valle, and F. P. Renno. 2018. Different durations of whole raw soybean supplementation during the prepartum period: Milk fatty acid profile and follicle and embryo quality of early lactating Holstein cows. J. Dairy Sci. 101:675-689. https:// doi.org/10.3168/jds.2016-12504.

Greco, L. F., J. T. Neves Neto, A. Pedrico, R. A. Ferrazza, F. S. Lima, R. S. Bisinotto, N. Martinez, M. Garcia, E. S. Ribeiro, G. C. Gomes, J. H. Shin, M. A. Ballou, W. W. Thatcher, C. R. Staples, and J. E. P. Santos. 2015. Effects of altering the ratio of dietary $\mathrm{n}-6$ to n-3 fatty acids on performance and inflammatory response to a lipopolysaccharide challenge in lactation Holstein cows. J. Dairy Sci. 98:602-617.

Grummer, R. R., D. G. Mashek, and A. Hayirli. 2004. Dry matter intake and energy balance in the transition period. Vet. Clin. North Am. Food Anim. Pract. 20:447-470.

Hart, K. A., M. H. Barton, M. L. Vandenplas, and D. J. Hurley. 2011. Effects of low-dose hydrocortisone therapy on immune function in neonatal horses. Pediatr. Res. 70:72-77.

Hasui, M., Y. Hirabayashi, and Y. Kobayashi. 1989. Simultaneous measurement by flow cytometry of phagocytosis and hydrogen peroxide production of neutrophils in whole blood. J. Immunol. Methods 117:53-58.

Hobson, P. N., and C. S. Stewart. 2012. The Rumen Microbial Ecosystem. Springer Sci. Bus. Media, New York, NY.

Hogan, S. P., H. F. Rosenber, R. Moqbel, S. Phipps, P. S. Foster, P. Lacy, A. B. Kay, and M. E. Rothenberg. 2008. Eosinophils: Biological properties and role in health and disease. Clin. Exp. Allergy 38:709-750.

Ioan-Facsinay, A., J. C. Kwekkeboom, S. Westhoff, M. Giera, Y. Rombouts, V. van Harmelen, T. W. Huizinga, A. Deelder, M. Kloppenburg, and R. E. Toes. 2013. Adipocyte-derive lipids modulate CD4+ T-cell function. Eur. J. Immunol. 43:1578-1587. 
Jenkins, T. C., R. J. Wallace, P. J. Moate, and E. E. Mosley. 2008. Recent advances in biohydrogenation of unsaturated fatty acids within the rumen microbial ecosystem. J. Anim. Sci. 86:397-412.

Kampen, A. H., T. Tollersrud, S. Larsen, J. A. Roth, D. E. Frank, and A. Lund. 2004a. Repeatability of flow cytometric and classical measurement of phagocytosis and respiratory burst in bovine polymorphonuclear leukocytes. Vet. Immunol. Immunopathol. 97:105-114.

Kampen, A. H., T. Tollersrud, and A. Lund. 2004b. Flow cytometric measurement of neutrophil respiratory burst in whole bovine blood using live Staphylococcus aureus. J. Immunol. Methods 289:47-55.

Kehrli, M. E., B. J. Nonnecke, and J. A. Roth. 1989. Alterations in the bovine neutrophil function during periparturient period. Am. J. Vet. Res. 50:207-214.

Kew, S., T. Banerjee, A. M. Minihane, Y. E. Finnegan, C. M. Williams, and P. C. Calder. 2003. Relation between the fatty acid composition of peripheral blood mononuclear cells and measures of immune cell function in healthy, free-living subjects aged 25-72 y. Am. J. Clin. Nutr. 77:1278-1286.

Kimura, K., J. P. Goff, and M. E. Kehrli Jr. 1999. Effects of the presence of the mammary gland on expression of neutrophil adhesion molecules and myeloperoxidase activity in periparturient dairy cows. J. Dairy Sci. 82:2385-2392.

Larbi, A., A. Grenier, F. Frisch, N. Douziech, C. Fortin, A. C. Capentier, and T. Fülöp. 2005. Acute in vivo elevation of intravascular triacylglycerol lipolysis impairs peripheral $\mathrm{T}$ cell activation in humans. Am. J. Clin. Nutr. 82:949-956.

Littell, R. C., G. A. Miliken, W. W. Stroup, R. D. Wolfinger, and O. Schabenberger. 2006. SAS ${ }^{\circledR}$ for Mixed Models. 2nd ed. SAS Inst. Inc., Cary, NC.

Lock, A. L., and D. E. Bauman. 2004. Modifying milk fat composition of dairy cows to enhance fatty acids beneficial to human health. Lipids 39:1197-1206.

Mehrzad, J., H. Dosogne, E. Meyer, R. Heyneman, and C. Burvenich. 2001. Respiratory burst activity of blood and milk neutrophils in dairy cows during different stages of lactation. J. Dairy Res. 68:399-415.

Onetti, S. G., and R. R. Grummer. 2004. Response of lactating cows to three supplemental fat sources as affected by forage in the diet and stage of lactation: A meta-analysis of literature. Anim. Feed Sci. Technol. 115:65-82.

Paape, M. J., D. D. Bannerman, X. Zhao, and J. W. Lee. 2003. The bovine neutrophil: Structure and function in blood and milk. Vet. Res. 34:597-627.
Petzold, M., U. Meyer, S. Kersten, G. Breeve, and S. Danicke. 2015. Impacts of CLA and dietary concentrate proportion on blood metabolite concentration and proliferation of peripheral blood mononuclear cells of periparturient dairy cows. Animal 9:481-489.

Poorani, R., A. N. Bhatt, B. S. Dwarakanath, and U. N. Das. 2016. COX-2, aspirin and metabolism of arachidonic, eicosapentaenoic and docosahexaenoic acids and their physiological and clinical significance. Eur. J. Pharmacol. 785:116-132.

Silvestre, F. T., T. S. Carvalho, N. Francisco, J. E. P. Santos, C. R Staples, T. C. Jenkins, and W. W. Thatcher. 2011. Effects of differential supplementation of fatty acids during the peripartum and breeding periods of Holstein cows: II. Neutrophil fatty acids and function, and acute phase proteins. J. Dairy Sci. 94:2285-2301.

Singh, J., R. D. Murray, G. Mshelia, and Z. Woldehiwet. 2008. The immune status of the bovine uterus during the peripartum period. Vet. J. 175:301-309.

Sordillo, L. M. 2016. Nutritional strategies to optimize dairy cattle immunity. J. Dairy Sci. 99:4967-4982.

Sordillo, L. M., G. A. Contreras, and S. L. Aitken. 2009. Metabolic factors affecting the inflammatory response of periparturient dairy cows. Anim. Health Res. Rev. 10:53-63.

Sordillo, L. M., and K. L. Streicher. 2002. Mammary gland immunity and mastitis susceptibility. J. Mammary Gland Biol. Neoplasia $7: 135-146$.

Ster, C., M. C. Loiselle, and P. Lacasse. 2012. Effect of postcalving serum nonesterified fatty acids concentration on the functionality of bovine immune cells. J. Dairy Sci. 95:708-717.

Stone, K. D., C. Prussin, and D. D. Metcalfe. 2010. IgE, mast cells, basophils, and eosinophils. J. Allergy Clin. Immunol. 125(Suppl. 2):S73-S80.

Tizard, I. R. 2014. Veterinary Immunology: An Introduction. 9th ed. I. R. Tizard, ed. Elsevier, London, UK.

Yaqoob, P., and P. C. Calder. 1995. The effects of dietary lipid manipulation on the production of murine T-cell-derived cytokines. Cytokine 7:548-553.

Zachut, M., I. Dekel, H. Lehrer, A. Arieli, A. Arav, L. Livshitz, S. Yakoby, and U. Moallem. 2010. Effects of dietary fats differing in n-6: n-3 ratio fed to high-yielding dairy cows on fatty acid composition of ovarian compartments, follicular status, and oocyte quality. J. Dairy Sci. 93:529-545.

Zerbe, H., N. Schneider, W. Leibold, T. Wensing, T. A. Kruip, and H. J. Schuberth. 2000. Altered functional and immunophenotypical properties of neutrophilic granulocytes in post-partum cows associated with fatty liver. Theriogenology 54:771-786. 